\title{
Preparation of Polyester Fabric with Asymmetric Wettability by Atmospheric Pressure Plasma Jet Treatments
}

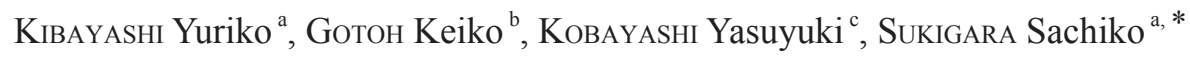 \\ ${ }^{a}$ Department of Advanced Fibro-Science, Kyoto Institute of Technology, Matsugasaki goshokaidocho, Sakyo-ku, \\ Kyoto, 606-8585, Japan \\ ${ }^{\mathrm{b}}$ National Institute of Technology, Nara College, 22, Yata-cho, Yamatokoriyama, Nara, 639-108, Japan \\ ${ }^{\mathrm{c}}$ Research Division of Electronic Materials, Osaka Research Institute of Industrial Science and Technology, 1-6-50, \\ Morinomiya, Joto-Ku, Osaka 536-8553, Japan
}

Received 19 February 2018; accepted for publication 20 April 2018

\begin{abstract}
Two types of atmospheric pressure plasma jet (APPJ) treatment were used to prepare the polyester fabric with asymmetric wettability, and then the wettability stability of the prepared fabric was examined. We investigated to make an asymmetric fabric by two methods using the APPJ treatments, and adopted the following method: After both sides of a polyester fabric were treated by the APPJ-coating, one side was subsequently treated by the APPJ-oxidation. The water contact angles on both sides of the prepared fabric were measured to be $150^{\circ}$ and $20^{\circ}$. The hydrophobic and hydrophilic stability of both sides was excellent for 7 days. From surface analyses, the granular surface morphology of deposited $\mathrm{SiO}_{2}$ films was observed on the APPJ-coated side of the polyester fabric, which caused water repellency. Silanol groups were produced after the subsequent APPJ-oxidation, which contributed to hydrophilicity. It was confirmed by the horizontal water spreading that the polyester fabric with an asymmetric wettability was successfully prepared.
\end{abstract}

Key Words: Atmospheric pressure plasma, Surface modification, Asymmetric wettability, Polyester fabric

\section{大気圧プラズマジェット処理による表裏非対称な ぬ机性をもつポリエステル布帛の作製}

\author{
木林有理子 ${ }^{\mathrm{a}}$, 後藤景子 ${ }^{\mathrm{b}}$, 小林靖之 ${ }^{\mathrm{c}}$, 鋤柄佐千子 ${ }^{\mathrm{a}, *}$ \\ ${ }^{a}$ 京都工芸瀻維大学工芸科学研究科, ${ }^{b}$ 奈良工業高等専門学校, ${ }^{c}$ 大阪産業技術研究所
}

\section{1. 緒 言}

近年, 生活者のニーズに合わせてアパレル製品の差別化を 罒るために，テキスタイルの高機能化が図られている。その ための主な手法として, ナノファイバー技術や複合加工技術 を用いた新規繊維の開発, 糸および布の構造構築, 布の表面 処理などが挙げられる $[1,2]$.

一般に, 表面処理は, 加工剂を用いたウェットプロセスと 気相中で処理が可能なドライプロセスに分類される.
ドライプロセスは繊維の強度低下や加工工程で生じる廃棄 物などがウェットプロセスと比較して生じにくいため, 環境 負荷抑制の視点から注目されている [3].さらに，ドライプ ロセスでは生産現場におけるインライン化と高速処理が可能 である。また, ウェットプロセスと異なり, 布の片面処理が できるため, 表裏で異なった性能をもつテキスタイルが作製 できる。

ドライプロセスの中でも, プラズマ処理は, 繊維製品への 応用をはじめ, 生体分野や電気電子分野などでの応用も期待

* 連絡先 : 京都工芸纎維大学 緘維学系 606-8585 京都市左京区松ヶ崎御所海道町 E-mail : sukigara@kit.ac.jp, Tel : +81-75-724-7365, Fax : +81-75-724-7365 
され，それにともなう処理条件の検討が報告されている [46]. とくに, 大気圧プラズマジェット（以下，APPJ）は大気 圧下において安定でかつ高密度なプラズマを生成するため, 簡便な表面改質が可能である。これまで, 後藤らは, 薬剤処 理の代替として，APPJ 処理を利用し，高分子フィルムおよ び布のぬれ性の制御，防污性の向上に関する検討を行ってき た $[7-15]$.

APPJ 処理には，通常の酸化処理に加えて，前駆体に有機 シラン化合物を用いたコーティング処理があり，この二つの 処理を用いて表面のぬれ性の制御をすることができる。すな わち, コーティング処理では表面の疎水化が, 酸化処理では 表面の親水化が可能である。布の各面にそれぞれコーティン グ処理と酸化処理を行えば，表裏で相反するぬれ性をもつ布 （以下，非対称布）を作製することができると考えられる。

非対称布を用いた衣服の性能として，衣服の外側は防水性 や水溶性污れの防污性が，身体側は吸汗性が期待できる。非 対称布は, 疎水性および親水性の二枚の布を張り合わせた二 層構造ではなく, 布一枚の一層構造をとるので, 夏物衣料な ど通気性を必要とする衣服への応用が期待できる.

従来行われている非対称布作製方法には，泡やスプレー法 による綿布の片面処理 [16,17], ゾルゲル法と UV 照射を組 み合わせた手法 [18] 並びに親水性繊維と疎水性纎維を組み 合わせた織物構造の構築 [19] がある。しかしながら，これ らは任意の布の両面に別々の処理を行う方法ではなく, 沉用 性に欠ける。最近, 我々はAPPJコーティング処理後のポリ エステル布表面を APPJ 酸化すると著しい親水化が起こるこ とを見出している $[20]$. この現象を利用して, 両面にAPPJ コーティング処理を行った布の片面のみを APPJ 酸化すれば、 非対称な好性をもつ布を作成できると考えられる。そ己 で本研究では，ポリエステルフィラメント布を試料として， APPJ コーティング処理およびAPPJ酸化処理を併用し，非対 称布の作製を試みる。そして処理後の布の表裏面のぬれ性と ぬれ安定性により，非対称布作製のための APPJ 処理条件を 見つける. またAPPJ 処理布の繊維表面の形態観察や化学分 析, 水滴のぬれ拡がり挙動を調べることで, 布の表毫面の親 水性，疎水性の違いの定量化をする.

\section{2. 実験方法}

\section{1 試料}

布試料はポリエステル平織布（タフタ，日本規格協会）を 用いた。糸番手は 8.3 tex (経糸および緯糸), 糸密度は $272 /$ $\mathrm{cm}$ (経糸) 並びに $246 / \mathrm{cm}$ (緯糸), 目付は $70 \mathrm{~g} / \mathrm{m}^{2}$ である. 実験に先立ち, $50 \sim 60^{\circ} \mathrm{C}$ の水中で 10 分間の超音波照射を 2 回繰り返して精製し，常温で乾燥させた。

APPJ コーティング処理並びにAPPJ 酸化処理での気体源に は窒素ガスを用いた [9].さらに，コーティング処理では， ヘキサメチルジシロキサン (HMDSO, 信越化学工業株式会 社 LS-7130）を前駆体として用いた.

水はミリポア製 Direct-Q UV(Millipore, USA)を用いて精
製した超純水（>18 M $\Omega \mathrm{cm} ）$ を使用した。

\subsection{APPJ 処理による布の表面処理}

前駆体を用いて薄膜を形成するプラズマコーティングと表 面酸化を行う通常のプラズマ酸化処理は同一の装置ではでき ない. そこで，2つの装置を用いた。 コーティング処理 $[21$, 22]は, Plasmatreat (Germany) 社製のPAD 1 を用いて行った. 直径 $5 \mathrm{~mm}$ のノズルジェットの先端から $15 \mathrm{~mm}$ 下の水平試料 台の上に布 $\left(200 \times 200 \mathrm{~mm}^{2}\right)$ を固定した。 プラズマジェット を噴出しながら, ノズル部分を $20 \mathrm{~m} / \mathrm{min}$, 送りピッチ $3 \mathrm{~mm}$ で左右に動かして処理した. HMDSO の流量は $0.66 \mathrm{~g} / \mathrm{min} に$ 調整した。

酸化処理 $[10]$ には Plasmatreat (Germany) 社製の FG1001を 用い, 直径 $40 \mathrm{~mm}$ のノズルジェットの先端から $5 \mathrm{~mm}$ 下の水 平試料台の上に布 $\left(200 \times 200 \mathrm{~mm}^{2}\right)$ を固定した。プラズマ ジェットを噴出しながら, 試料台を $10 \mathrm{~m} / \mathrm{min}$ で左右に動かし, 処理を行った

いずれの処理でも気体源に窒素ガスを用い, 圧力 $0.3 \mathrm{MPa}$, 並びに流量 $33.3 \mathrm{dm}^{3} / \mathrm{min}$ とした。

本研究では, 上記 2 種の APPJ 処理を組み合わせ, 二つの 方法で非対称布の作製を試みた。一つは布試料の片面にコー ティング処理を行い, もう一方の面に酸化処理を行う方法で ある.もう一つの方法は布試料の両面にコーティング処理を 行った後，片面に酸化処理を行う方法である.

\section{3 布表面に対する水の接触角測定}

非対称布のぬれ性を評価するために，AST 社製 VCA-2500 を用いて, sessile drop 法により水の接触角を測定した。試験 布 $\left(10 \times 40 \mathrm{~mm}^{2}\right)$ 表面に $2 \sim 3 \mu 1$ の超純水を滴下した瞬間 からの水滴画像を CCD カメラで撮影し, コンピューター処 理により滴下 1 秒後の接触角を算出した [23]. 接触角測定 は $20 \pm 11^{\circ} \mathrm{C}, 65 \pm 2 \% \mathrm{RH}$ の恒温恒湿室中で行った。

\section{4 繊維表面のキャラクタリゼーション}

APPJ 処理前後の繊維の表面形態観察には走査型電子顕微 鏡（SEM，日立ハイテク社製 SU1510）を用いた。コーティン グ装置（エリオニクス製 ESC- 101）を用いて，布試料 $(5 \times$ $\left.5 \mathrm{~mm}^{2}\right)$ に200 秒間のタングステン蒸着をし, 加速電圧 $5 \mathrm{kV}$ で観察した。

処理後の繊維表面の化学組成は X 線光電子分光分析装置法 （XPS，島津 Kratos 製 AXIS- ULTRA DLD）を用いて調べた. $\mathrm{X}$ 線源には単色化した $\mathrm{A} 1 \mathrm{~K} \alpha$ 線 $(1486.7 \mathrm{eV})$ を用いた。布試 料 $\left(10 \times 10 \mathrm{~mm}^{2}\right)$ を試料ホルダーに固定し，パスエネルギー $20 \mathrm{eV}$ でスペクトルを得た。分析面積は $0.3 \times 0.7 \mathrm{~mm}^{2}$, 光電 子の取り込み角は $90^{\circ}$, 分析チャンバー内の圧力は $10^{-8} \mathrm{~Pa}$ 以 下である。 


\section{5 布の吸水性の評価}

非対称布の吸水性は JIS L 1907 の滴下法 [24] を参考に, 水滴のぬれ拡がり面積を測定して評価した。 ガラス製シャー レ（直径 $50 \mathrm{~mm}$ ）上に，プラスチック製の枠に固定した布試 料 $\left(24 \times 35 \mathrm{~mm}^{2}\right)$ を水平に置き, 中央に超純水 $5 \mu 1$ を滴下し, 滴下した瞬間から 60 秒後までの布表面の画像をデジタルカ メラで動画撮影した。各時間での静止画像を画像処理ソフト （三谷商事社製 WinROOF 6.3.1）により二值化し，布試料上 の水滴のぬれ拡がり面積を算出した.

\section{3. 結果と考察}

\section{1 非対称布作製のための APPJ 処理条件の検討}

APPJ 酸化処理回数が水の接触角に及ぼす影響を Fig. 1 に示 す。ポリエステル布の未処理面の接触角は約 $120^{\circ}$ であった。 未処理面に酸化処理を行うと, 処理回数とともに接触角が低 下し，12 回以上の処理で接触角はほぼ $20^{\circ}$ となった。未処理 面にコーティング処理を行うと接触角は約 $150^{\circ}$ と超撥水性を 示した。コーティング処理面に酸化処理を行うと接触角が低 下し，12 回以上で約 $20^{\circ}$ になった。そこで，未処理面および コーティング処理面のいずれを酸化する場合も, APPJ 酸化処 理は 12 回とした。

次に, 処理面の好安定性を確認するために, 接触角の 経時変化を調べた結果を Fig. 2 に示す。コーティング処理後 の接触角は極めて安定であった

印，Fig. 2)。しかしなが ら，未処理面に酸化処理を行った場合，経過日数とともに接 触角の増加が認められた（○印，Fig. 2)。これは疎水性回復 と呼ばれ, 表面層内の分子の再配向やマイグレーションに起 因すると考えられている [8]. 一方，コーティング処理面に 酸化処理を行った場合, 接触角の増加は殆どなかった（ $\triangle$ 印， Fig. 2).

以上の結果から, 非対称布の作製方法として, 試験布の両 面にAPPJ コーティング処理を行い，次に片面にAPPJ 酸化 処理を 12 回行う方法を用いることにした。 3.2 以下では，こ の方法で作製 1 週間後の試料で得られた結果を示す。

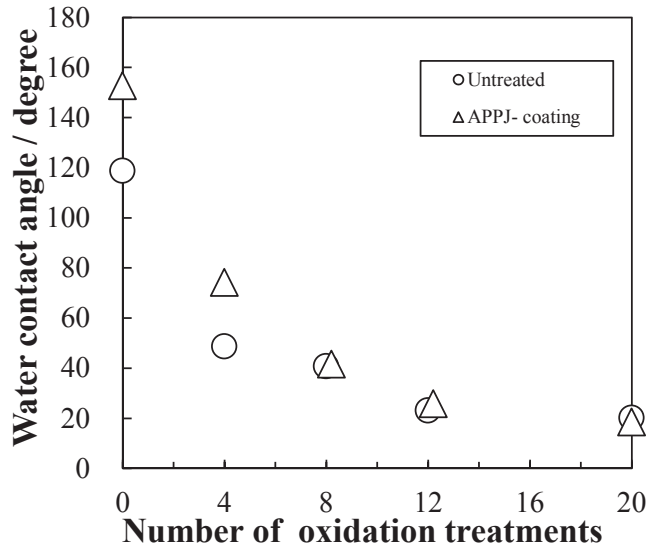

Fig. 1 Effect of number of APPJ-oxidation on water contact angle on the polyester fabric.

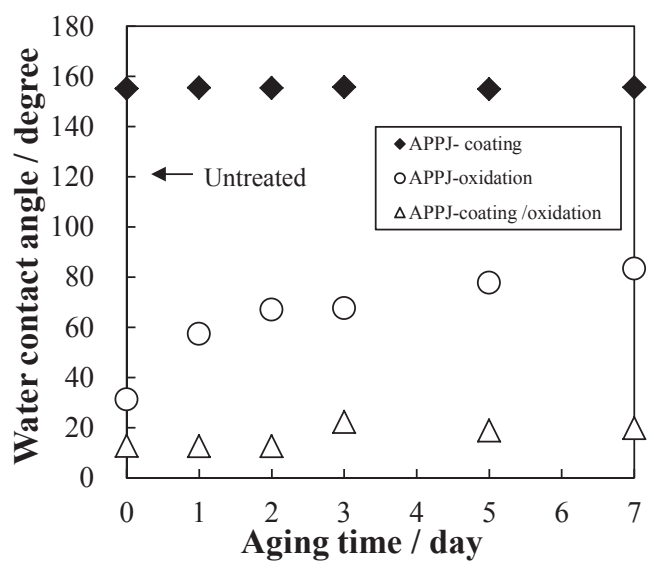

Fig. 2 Change in water contact angle on the polyester fabric with aging time.

\section{2 表面化学組成および形態観察}

ポリエステル布未処理面および作製した非対称布両面の SEM 画像を Fig. 3 に示す。未処理面の繊維表面はなめらかで あった（Fig. 3 (a)). APPJ コーティング面では繊維表面に粒 状の凹凸突起が観察され (Fig. 3 (b)), 前駆体 HMDSO を用 いたプラズマ重合に関する研究でも同様の報告がされている
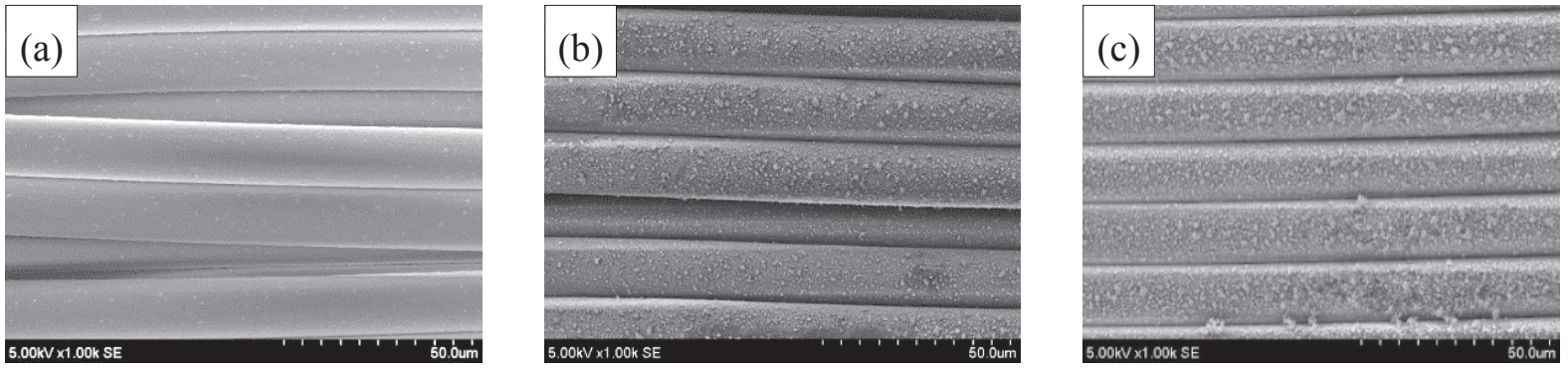

$\overline{20 \mu \mathrm{m}}$

Fig. 3 SEM images of the polyester fabric. (a) Untreated, (b) APPJ-coating, (c) APPJ-coating/oxidation. 
Table 1 Surface atomic concentrations on the polyester fabric obtained from XPS spectra.

\begin{tabular}{ccccc}
\hline & \multicolumn{4}{c}{ Atomic concentration (\%) } \\
\cline { 2 - 5 } & $\mathrm{C}$ & $\mathrm{O}$ & $\mathrm{Si}$ & $\mathrm{N}$ \\
\hline Untreated & 74.9 & 25.1 & 0.0 & 0.0 \\
APPJ-coating & 33.1 & 40.9 & 24.6 & 1.3 \\
APPJ-coating /oxidation & 19.1 & 55.3 & 24.7 & 1.0 \\
\hline
\end{tabular}

[25-27].この凹凸形状が超撥水性の発現に寄与したと考え られる $[28]$. APPJ コーティング後, 酸化処理をしても表面 形態に大きな差は認められず (Fig. 3 (c)), コーティングに よって形成された凹凸構造を維持していた。

XPS ナロースペクトルにより得られた䋊維表面の化学組成 を Table 1 に示す. 未処理布ではポリエステルの化学構造から 推察される原子組成 (C: $74.9 \%, O: 25.1 \%$ ) と同程度の值が得 られた $[10,11]$. また，非対称布では，いずれの処理面にお いても窒素のピークが検出され, 気体源に用いた窒素ガス由 来であると示唆される。コーティング面では，C, O 以外に $\mathrm{Si}$ が主成分として検出された. Si はAPPJコーティング処理に前 駆体として用いた HMDSO 由来で， Si と O の比はおよそ $1: 2$ であった。一方, HMDSO のケイ素と酸素の比率は $2: 1$ であ ることから, $\mathrm{SiO}_{2}$ の組成に近い化合物が生成すると考えられ る.

Fig. 4 にC 1s ナロースペクトルを示す. 未処理のスペクトル (Fig. 4 (a)) と比較すると,コーティング面（Fig. 4 (b)）では ポリエステルに由来する $\mathrm{C}-\mathrm{O}$, および $\mathrm{O}-\mathrm{C}=\mathrm{O}$ のピークが消 失していることから, 繊維全体にわたってコーティングされ ていることがわかる. APPJコーティング処理後に酸化処理 することで, コーティング膜表面上の不純物が除去され, コー ティング膜中のシリカと水酸基が結合し，シラノール基を形 成したため，ぬれ性が向上したと考えられる $[29 ， 30]$ 。また，

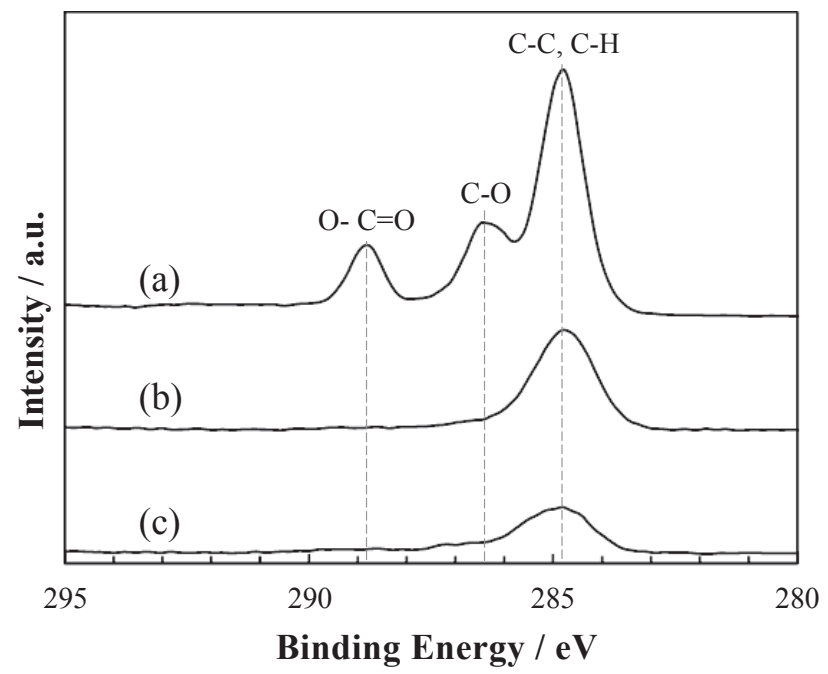

Fig. 4 XPS C1s narrow spectra of the polyester fabric. (a) Untreated, (b) APPJ-coating, (c) APPJ-coating/oxidation.

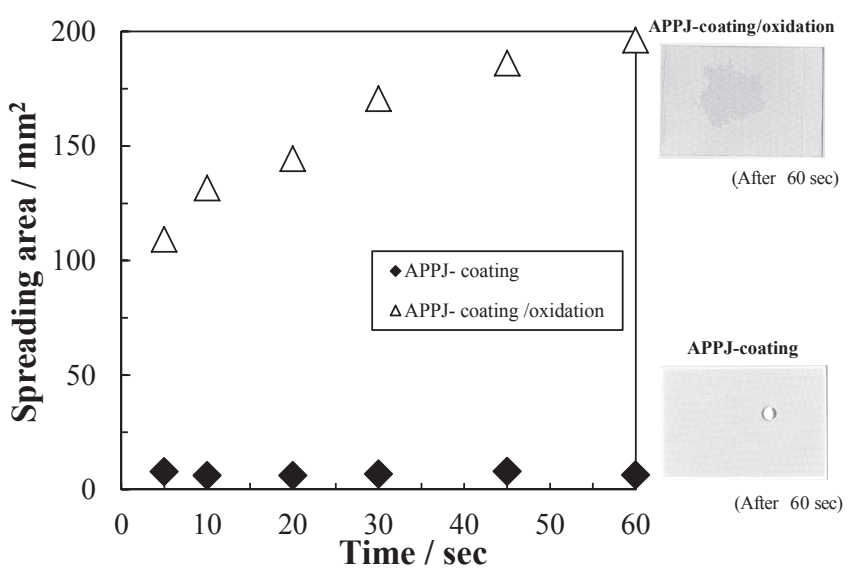

Fig. 5 Change in spreading area of water drop on the polyester fabric with time.

ぬれ性が安定であった理由として，シラノール基の結合状態 に起因すると考えられるが，今回の検討では明らかとなって いない.

\section{3 非対称布の吸水性評価}

ポリエステル非対称布の表裏面上の水滴のぬれ拡がり面積 と時間の関係，並びに 60 秒後の画像を Fig. 5 に示す. APPJ コーティング面では, 60 秒後の水滴は球形のままであり, 水 滴のぬれ拡がりがなかった。一方, APPJ コーティング/酸 化面では，短時間で水滴が著しく拡がり，時間とともに拡が り面積は増大した。APPJ 処理により, 布の両面で吸水性が 顕著に異なる非対称布が作製できたことが確認された。

\section{4. 結 言}

APPJ コーティング処理およびAPPJ 酸化処理を用いて, 両 面のぬれ性が異なる非対称ポリエステル布の作製を試みたと ころ，次のことがわかった。

1. 2 種類の APPJ 処理を用いて, 1 枚の布の表裏でぬれ性の 異なる非対称布が作製できた。

2. 両面に 1 回のコーティング処理を行ったのち, 片面に 12 回の酸化処理を行う方法で作製した非対称布の接触角は, 疎水性面で $150^{\circ}$ と, 親水性面で $20^{\circ}$ を示した。さらに, 作製後の接触角に変化がなく，ぬれ性は安定していた。

3. コーティング処理面では粒状突起が観察され, 二酸化ケ イ素 $\mathrm{SiO}_{2}$ から成ることが示唆された。 この表面凹凸形状 により超撥水性を発現したと考えられる。コーティング 処理面を酸化すると，シラノール基が形成され，接触角 が小さくなったと考えられた。

4. 非対称布の吸水性は, 表裏で大きく異なることが確認さ れた。 


\section{謝 辞}

プラズマコーティング処理に関して，装置の提供を頂きま したプラズマトリート株式会社 丹羽秀人様に深謝申し上げ ます。

本研究は平成 29 年度科学研究費補助金（挑戦的萌芽研究, 課題番号 $15 \mathrm{~K} 12315$, 研究代表者: 後藤景子) により行った.

\section{References}

[1] Shiotani T (2011) Sen'i Gakkaishi, 67, 373-381 (in Japanese)

[2] Shiotani T (2016) Sen'i Gakkaishi, 72, 581-586 (in Japanese)

[3] S Luo, WJ Van Ooij (2002) J Adhesion Sci Technol, 16, 1715-1735

[4] K Fang, C Zhang (2009) Appl Surf Sci 255, 7561-7567

[5] G M L Messina, C Satriano, G Marletta (2009) Colloids Surf B Biointerfaces, 70, 76-83

[6] B Paosawatyanyong, K Kamlangkla, S K Hodak (2010) J Nanosci Nanotechnol, 10, 7050-7054

[7] Gotoh K, Yasukawa A (2010) Text Res J, 81, 368-378

[8] Gotoh K, Yasukawa A, Taniguchi T (2011) J Adhesion Sci Technol, 25, 307-322

[9] Gotoh K, Saita K, Ooki M (2012) J Home Econ Jpn, 63, 125-132 (in Japanese)

[10] Gotoh K, Yasukawa A, Kobayashi Y (2012) Sen'i Gakkaishi, 68, 19-26 (in Japanese)

[11] Gotoh K, Kobayashi Y, Yasukawa A, Ishigami Y (2012) Colloid Polym Sci, 290, 1005-1014

[12] Gotoh K, Yoshitaka S (2013) Text Res J, 83, 1606-1614

[13] Gotoh K, Katsuura A, Honma A, Kobayashi Y (2013) Sen'i Gakkaishi, 69, 169-176

[14] Gotoh K, Shohbuke E, Kuroda Y, Kobayashi Y (2016) Polym
J, 48, 889-896

[15] Gotoh K, Kawamoto N, Shohbuke E, Kobayashi Y (2016) J Fiber Sci Tech, 72, 80-88 (in Japanese)

[16] Y Liu, J H Xin, C H Choi (2012) Langmuir, 28, 17426-17434

[17] Sasaki K, Tenjimbayashi M, Manabe Y, Shiratori S (2016) ACS Appl Mater Interfaces, 8, 651-659

[18] H Wang, J Ding, L Dai, X Wang, T Lin (2010) J Mater Chem, 20, 7938-7940

[19] Guilford Mills, Inc (1991) United States Patent US 5065600 A

[20] Shoubuke E, Gotoh K, (2018) J Jpn Res Assn Text End-Uses, in press (in Japanese)

[21] M Wolter, S Bornholdt, M Hackel, H Kerster (2009) J Achiev Mater Manuf Eng, 37, 730-734

[22] V Raballand, J Benedikt, S Hoffmann, M Zimmermann, A von Keudell (2009) J Appl Phys, 105, 083304, 1-6

[23] Gotoh K, Tagawa M, Ohmae N, Kinoshita H, Tagawa M (2001) Colloid Polym Sci, 279, 214-220

[24] Japanese Standards Association (2007) "JIS handbook: Testing method of woven fabrics", 1719-1812 (in Japanese)

[25] Baba K, Hatada R (1993), J Surf Finishing Soc Jpn, 44, 817820 (in Japanese)

[26] S Zanini, C Riccardi, M Orlndi, E Grimoldi (2008) Vacuum, 82, 290-293

[27] L F Mobarakeh, R Jafari, M Farzaneh (2011) Adv Mat Res, 409, 783-787

[28] Onda T (1996) IEEJ A, 116, 1041-1046 (in Japanese)

[29] Kuwahata H, Ohyama R (2009) J Surf Sci Soc Jpn, 30, 174179 (in Japanese)

[30] Teshima K, Inoue Y, Sugimura H, Takai O (2003) J Surf Finish Soc Jpn, 54, 698-703 (in Japanese) 